\title{
ACUTE HAEMORRHAGIC LEUCO-ENCEPHALITIS
}

BY

\author{
T. CRAWFORD
}

From the Department of Pathology, St. George's Hospital Medical School, London

(RECEIVEd For PUblication AUGUSt 25, 1953)

- It was in 1940 that Weston Hurst (1941) encountered two cases of fatal encephalitis which he regarded on clinical and pathological grounds as representing a previously unidentified entity to which he gave the name of acute haemorrhagic leuco-encephalitis. To quote Hurst's original description, the disease was "an acute cerebral condition, virtually localized as far as the cerebrum was concerned to the white matter, and developing more or less abruptly in apparently normal individuals. Perivascular necroses, perivascular and focal demyelination, haemorrhages, oedema, and cellular infiltration were the chief components of the pathological picture."

In the 12 years since Hurst's paper appeared remarkably few similar cases have been reported, and in fact only five further examples have been described under the same name. These have been recorded by Henson and Russell (1942), Shallard and Latham (1945), MacArdle, van Bogaert, and Lhermitte (1949, two cases) and by Greenfield (1950). It so happens that three characteristic examples of the disease have occurred in the neurosurgical department of St. George's Hospital over a two-year period, and it seems probable that the condition is not such an extreme rarity as the small number of recorded cases would indicate. The object of the present communication is to put on record these three further cases (bringing the number recorded up to 10 ) and to draw the attention of general pathologists to the existence of this variety of encephalitis. The descriptions of the disease which follow are based on the three new cases together with the seven previously reported. More detailed summaries of the three cases are included in an appendix to this paper.

\section{Clinical Features}

The salient clinical features are summarized in Table I. The age of the patients has varied from 2 years 10 months (Case 2 of the present series) to 51 years (Greenfield, 1950), but seven of the 10 patients were young adults in the third and fourth decades. The sex incidence shows a male preponderance with seven male and three female patients. The duration of the disease has proved variable. In seven cases the onset of neurological signs was

TABLE I

SUMMARY OF CLINICAL COURSE

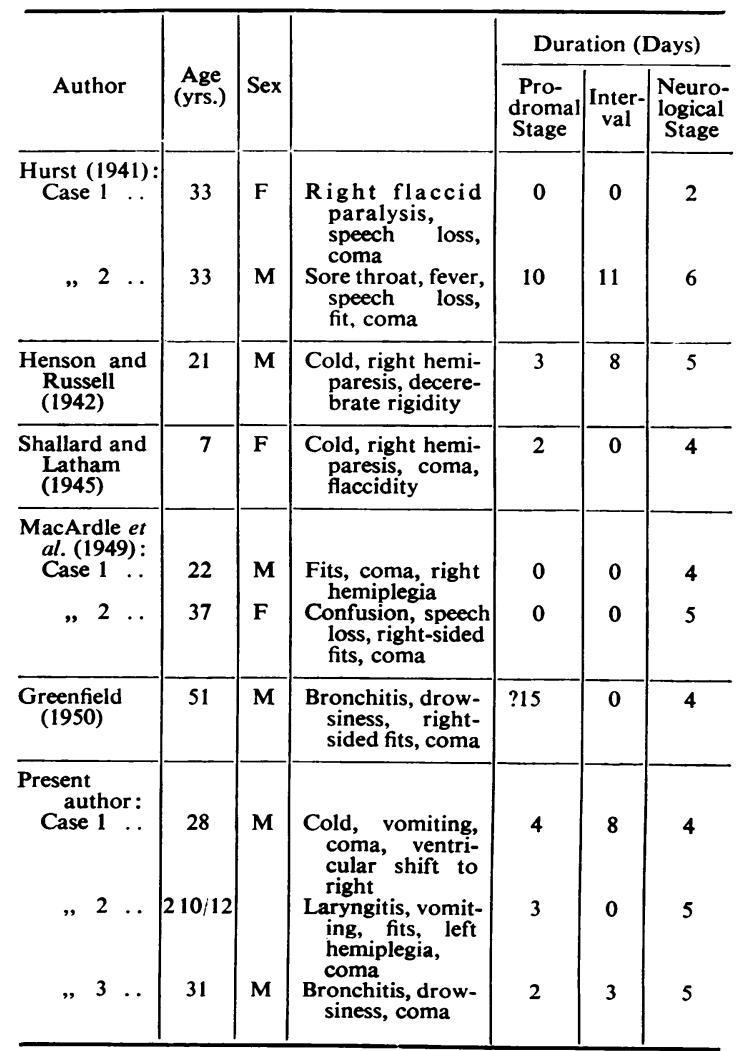

preceded by a prodromal period of upper respiratory infection lasting from as little as two days up to about 15 days, and in four cases the prodromal infection was separated from the encephalitic stage by a few days of apparent recovery. The longest survival after the onset of 
neurological signs was six days, while Hurst's original patient died after only 42 hours' illness.

A detailed account of the symptoms and signs is beyond the scope of this paper. Striking features, however, are the early onset of coma and the frequent gross asymmetry of the signs. This asymmetry has been conspicuous in nine of the 10 cases and has sometimes led to needling of the brain in search of an abscess or other focal lesion. Six cases have shown right hemiparesis with early speech involvement.

\section{Clinical Pathology}

It is unfortunate that few laboratory tests have been recorded on material obtained from these patients during life - a fact no doubt associated with the rapid downhill course of most cases. Such information as is available is summarized in Table II. In the cerebrospinal fluid the cell count varied

TABLE II

CLINICO-PATHOLOGICAL FINDINGS

\begin{tabular}{|c|c|c|c|c|c|c|}
\hline \multirow[b]{2}{*}{ Author } & \multicolumn{3}{|c|}{ Cerebrospinal Fluid } & \multicolumn{2}{|c|}{ Blood } & \multirow[b]{2}{*}{ Urine } \\
\hline & $\begin{array}{c}\text { Cells } \\
\text { (per } \\
\text { c.mm.) }\end{array}$ & $\begin{array}{l}\text { Poly- } \\
\text { morphs } \\
(\%)\end{array}$ & $\begin{array}{c}\text { Protein } \\
(\mathrm{mg} . \\
100 \mathrm{ml} .)\end{array} \mid$ & \begin{tabular}{|l} 
White \\
Cells \\
(per \\
c.mm.)
\end{tabular} & $\mid \begin{array}{c}\text { Poly- } \\
\text { morphs } \\
(\%)\end{array}$ & \\
\hline $\begin{array}{c}\text { Hurst (1941): } \\
\begin{array}{rll}\text { Case } & 1 & \ldots \\
\Rightarrow & 2 & \ldots\end{array}\end{array}$ & 二 & 二 & - & $22, \overline{900}$ & 二 & 二 \\
\hline $\begin{array}{l}\text { Henson and } \\
\text { Russell } \\
\text { (1942) }\end{array}$ & $\begin{array}{l}0 \\
6\end{array}$ & - & $\begin{array}{l}40 \\
35\end{array}$ & $\begin{array}{c}12,000 \\
-\end{array}$ & $\begin{array}{l}82 \\
-\end{array}$ & $\begin{array}{l}\text { Albumin } \\
+++ \\
\text { Casts }++\end{array}$ \\
\hline $\begin{array}{l}\text { Shallard and } \\
\text { Latham } \\
\text { (1945) }\end{array}$ & 200 & 90 & 30 & - & - & - \\
\hline $\begin{array}{c}\text { MacArdle et } \\
\text { al. (1949): } \\
\text { Case } 1 \text {.. } \\
, 2 \quad 2 \quad .\end{array}$ & $\overline{6}$ & 二 & $\overline{55}$ & 二 & - & Albumin \\
\hline $\begin{array}{l}\text { Greenfield } \\
\text { (1950) }\end{array}$ & 342 & 84 & 60 & 一 & - & - \\
\hline $\begin{array}{rll}\text { Present } & & \\
\text { author : } & \\
\text { Case } & \mathbf{1} & \ldots \\
\# & \mathbf{2} & \ldots \\
\# & \mathbf{3} & \ldots\end{array}$ & $\begin{array}{r}220 \\
2 \\
150\end{array}$ & $\frac{84}{71}$ & $\begin{array}{r}80 \\
30 \\
140\end{array}$ & $30, \overline{000}$ & $\overline{81}$ & $\begin{array}{c}\text { No protein } \\
\text { " } " \#\end{array}$ \\
\hline
\end{tabular}

from normal up to a count of 341 per c.mm. and the elevated counts were always associated with considerable numbers of polymorphonuclear leucocytes, the proportion of these cells always exceeding $70 \%$ with total counts over 100 per c.mm. The cerebrospinal fluid protein level was also moderately elevated in most cases, the highest level noted being $140 \mathrm{mg}$. per $100 \mathrm{ml}$. (present series, Case 3). The cell and protein increases were approximately proportionate except for the case of Shallard and Latham (1945) in which the cerebrospinal fluid showed a cell count of 200 per c. mm. (90\% polymorphs) but a protein level of only $30 \mathrm{mg}$. per $100 \mathrm{ml}$. Three observations of the cerebrospinal fluid sugar and chloride levels fall within normal limits. Blood counts were recorded in only three cases, two showing a high and the third a moderate leucocytosis, while two differential counts both revealed polymorphonuclear increase. Examination of the urine was not recorded in five of the cases. Of the others, one showed heavy albuminuria with casts (Henson and Russell, 1942) and one slight albuminuria (MacArdle et al., 1949, Case 2). In the three cases of the present series protein was absent from the urine at a single examination in each.

\section{The Naked-eye Lesions}

The meninges have usually shown no naked-eye change, but sometimes they appear congested (Henson and Russell, 1942 ; present series Cases 1 and 3). Greenfield (1950) noted some creamy exudate over the convexity of the left frontal lobe. The most characteristic lesion is seen in the white matter of the cerebral hemispheres and takes the form of haemorrhages varying in size from minute points up to areas a few millimetres in diameter, which, in the more severely involved regions, may become confluent (Fig. 1). These more affected parts show asymmetrical oedematous swelling with

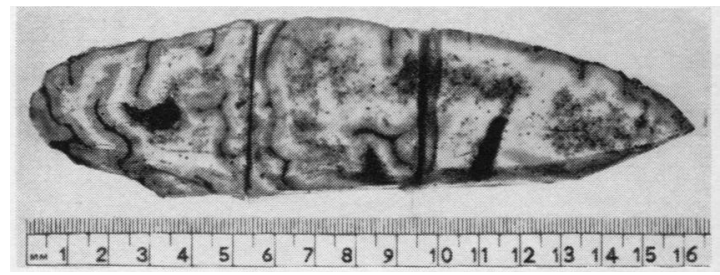

FIG. 1.-Three pieces of the left cerebral hemisphere from Case 1 . Petechial haemorrhages, in places confluent, are scattered throughout the white matter and there is haemorrhage in the track of an exploratory needle.

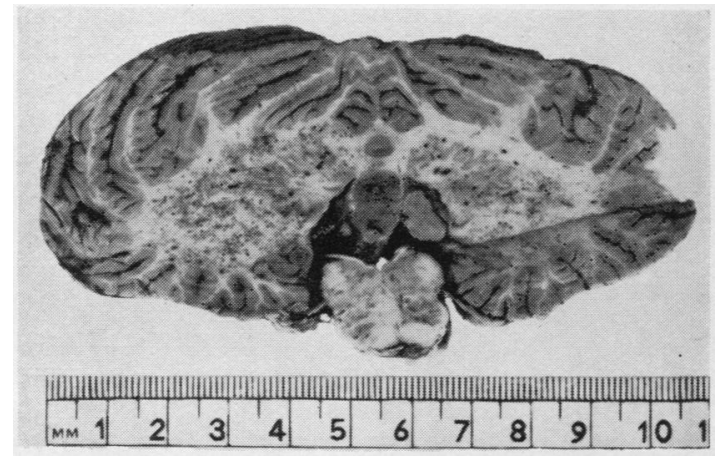

FIG. 2.-Cerebellum and brain-stem from Case 3. There are numerous petechial haemorrhages in the white matter. 


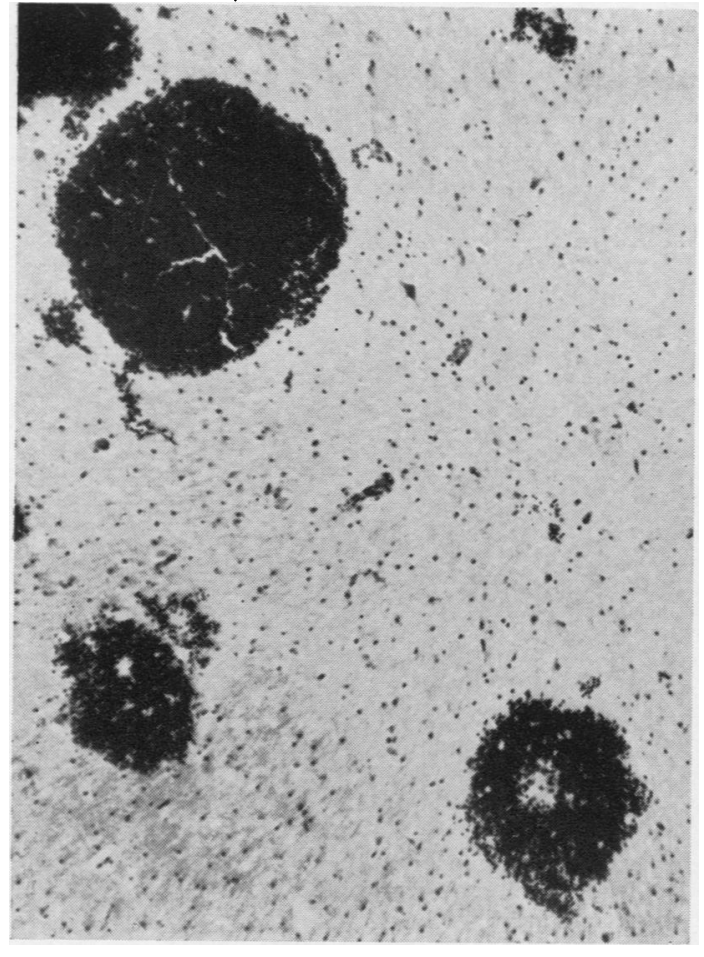

FIG. 3

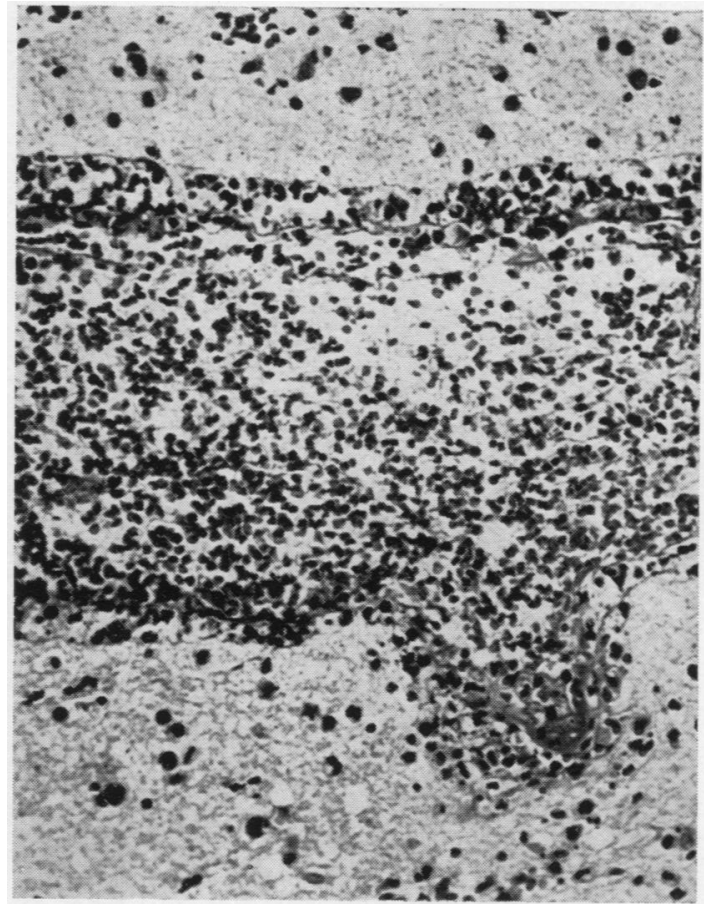

Fig. 5
Fig. 3.-Ball and ring haemorrhages in the parietal white matter (Case 1). Phloxinetartrazine $\times 45$.

Fig. 4.-Disrupted capillary in the centre of a ball haemorrhage (Case 1). Picro-Mallory

FIG. 5.-Leucocytic exudate, chiefly polymorphonuclear, in the sheath of a small vein (Case 2). Haematoxylin and eosin $\times 180$.

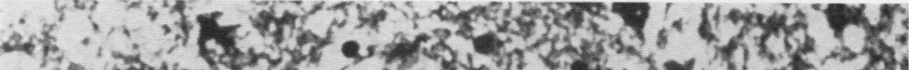
2 dy 5.t. - s. 3.2.

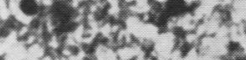
7 .

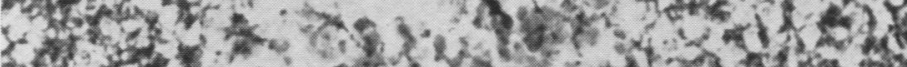

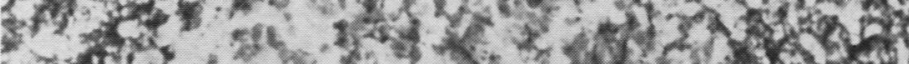
3) 7 .

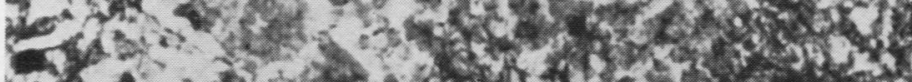
Q.

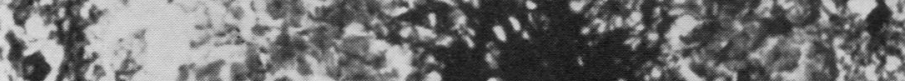

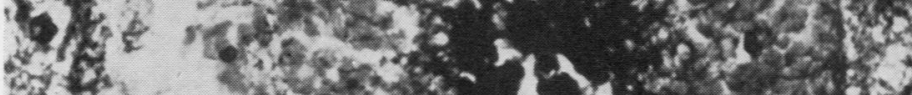

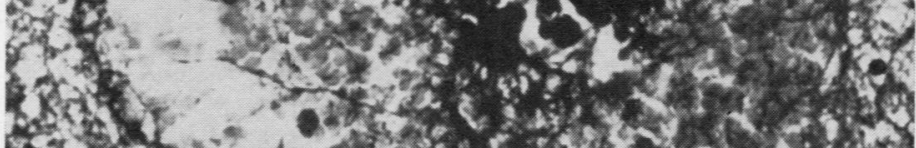

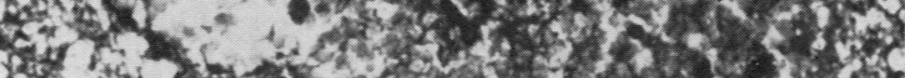
3. 350 -

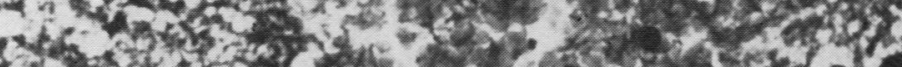

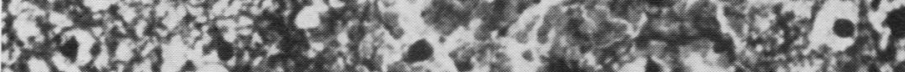

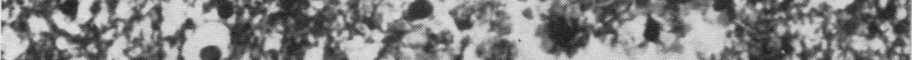

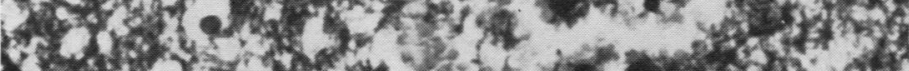

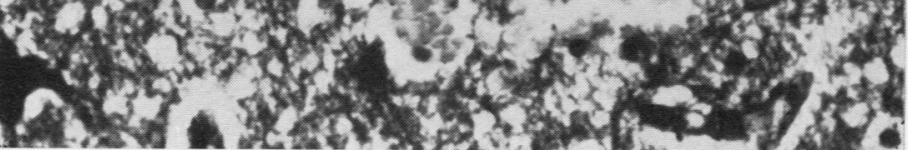




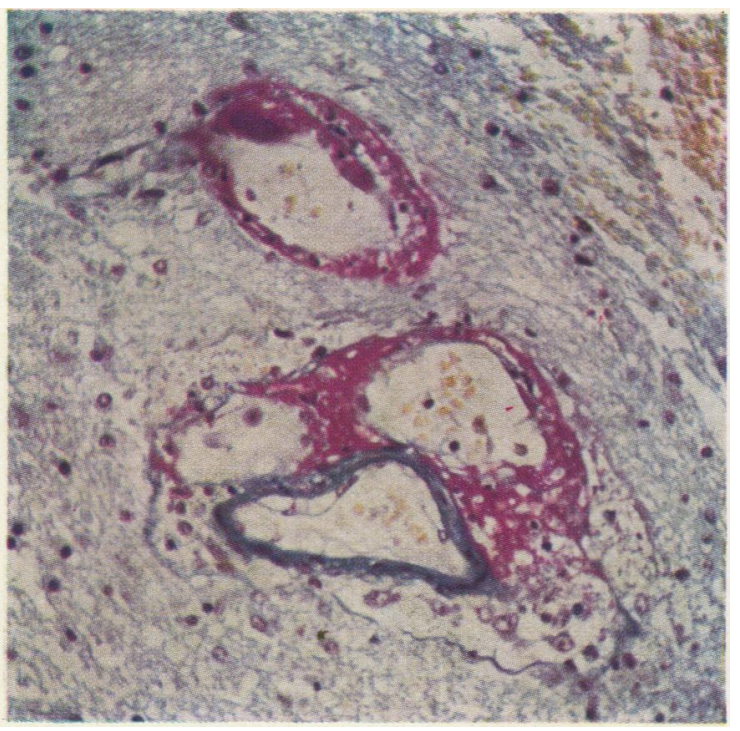

Fig. 6

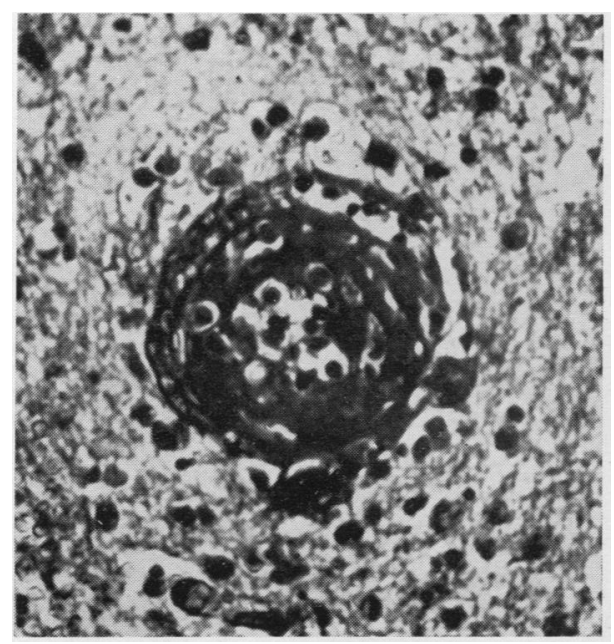

Fig. 8

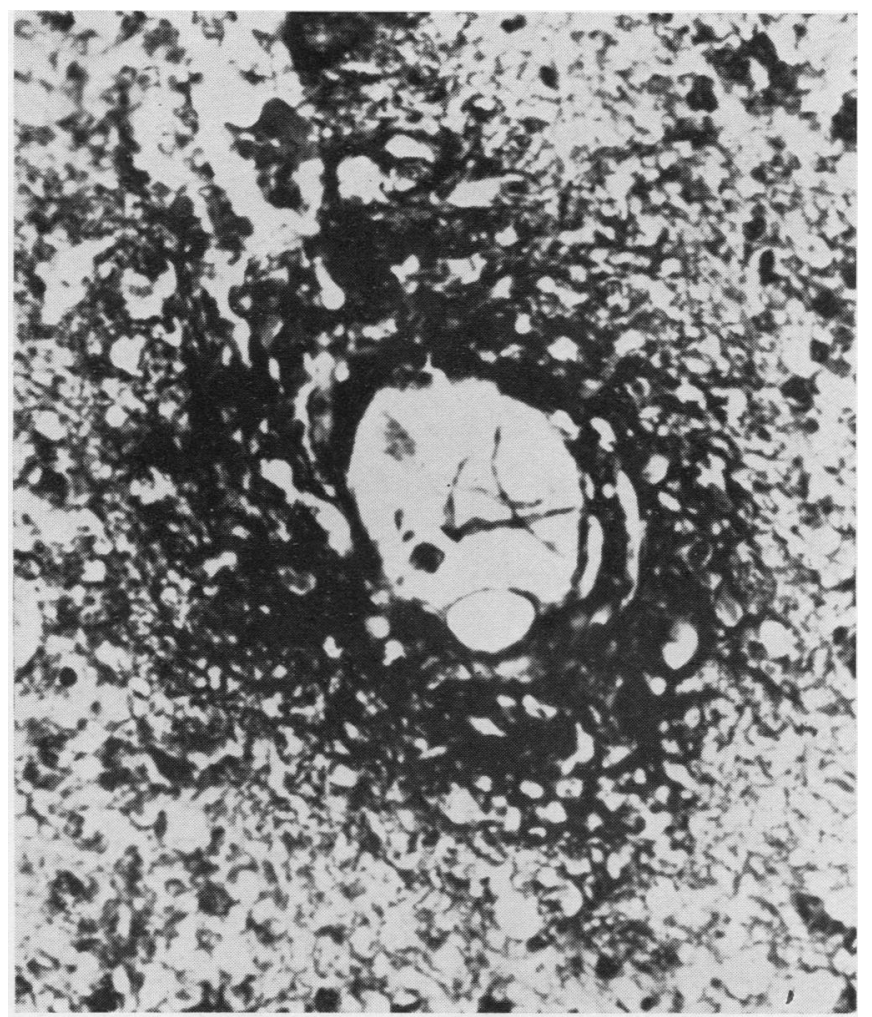

FiG. 6.-Fibrin impregnation of the walls of venules in the white matter (Case 2). Acidpicro-Mallory $\times 175$.

FIG. 7.-Fibrin impregnation extending through the vessel wall into the adjacent white matter (Case 1). Acid-picro-Mallory $\times 312$.

FIG. 8.-Fibrin deposit around the lining of a venule and extending through the wall to the perivascular sheath (Case 1). Acidpicro-Mallory $\times 312$.

FIG. 9.-Fibrin-plugged capillaries in the white matter (Case 2). Acid-picro-Mallory $\times 130$.

Fig. 10.-Multiple foci of demyelination in the cerebellar white matter (Case 3). Loyez $\times 35$.

FIG. 11.-Demyelination in an area of haemorrhage (Case 3). Loyez $\times 100$.

FIG. 12.-Perivascular demyelination (Case 3). Loyez $\times 120$.

Fig. 7 


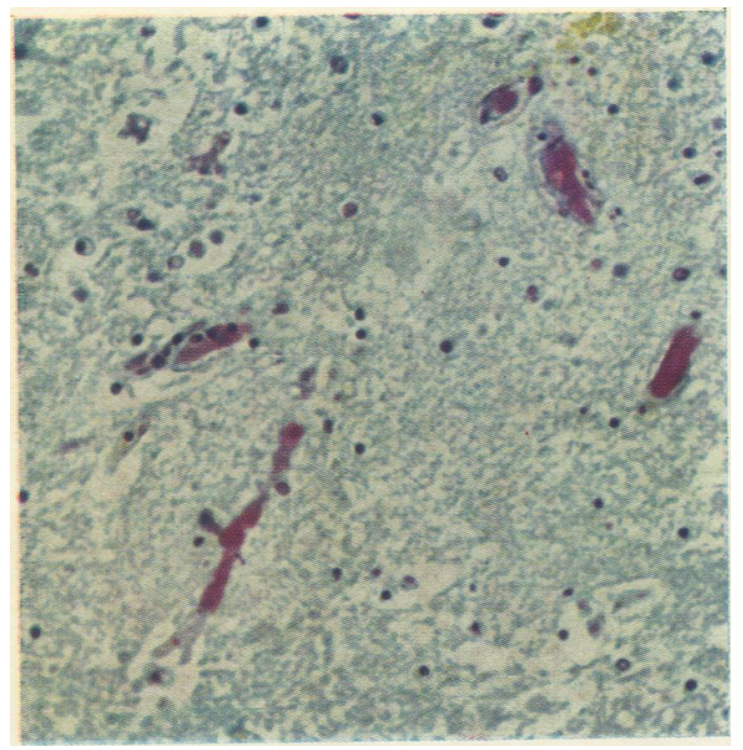

FIG. 9

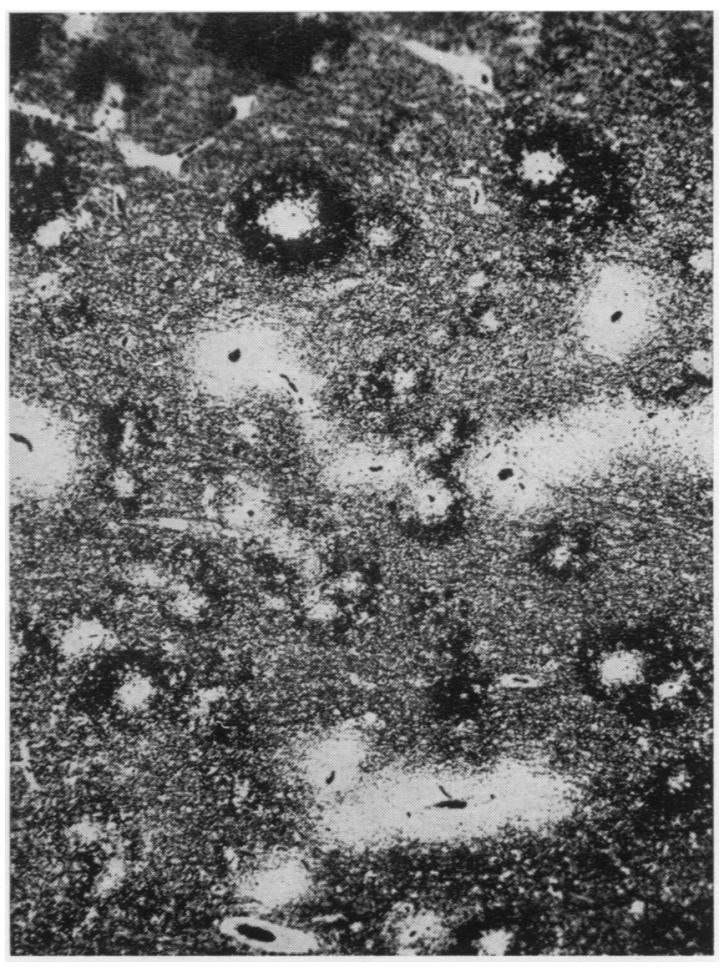

FIG. 10

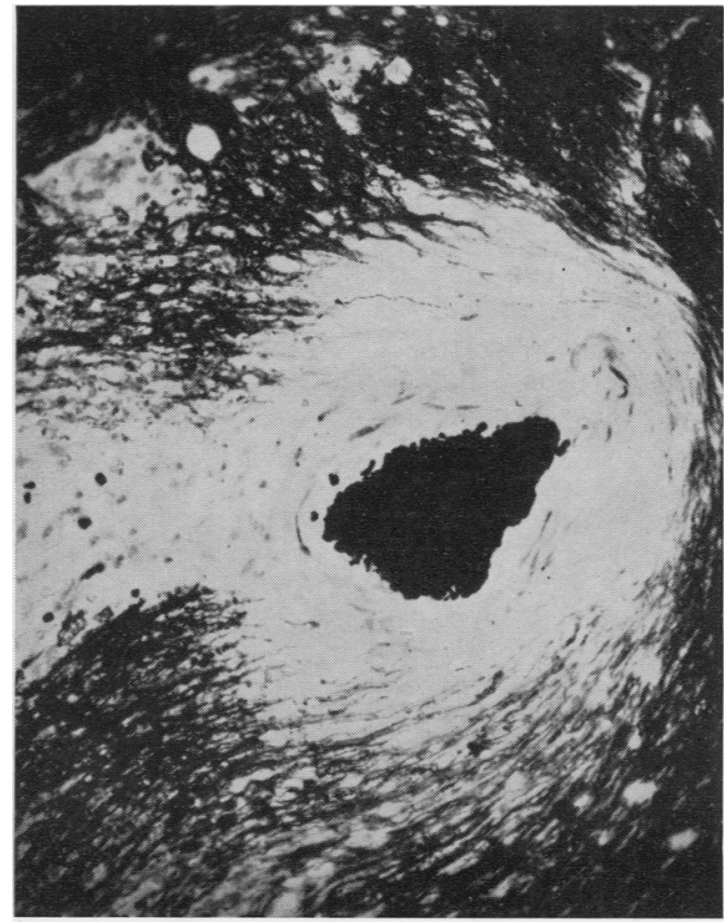

FIo. 12 
pinkish or grey discoloration and the most severely hit area may be of an almost gelatinous consistency.

The distribution of these lesions is highly characteristic and is summarized in Table III. The haemorrhages involve the white matter only, the grey matter showing nothing more than some vascular engorgement. The central white matter of one or both cerebral hemispheres is regularly involved and in most cases has shown the most severe lesions. The haemorrhages may extend into the white cores of the convolutions, but the $\mathrm{U}$-fibres between adjacent convolutions are usually

TABLE III

DISTRIBUTION OF NAKED-EYE AND MICROSCOPICAL

\begin{tabular}{|c|c|}
\hline Author & Areas Affected \\
\hline $\begin{array}{l}\text { Hurst (1941): } \\
\text { Case } 1\end{array}$ & 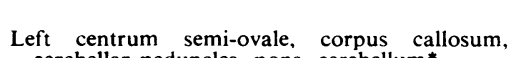 \\
\hline, 2 & $\begin{array}{l}\text { cerebellar peduncles, pons, cerebellum* } \\
\text { Left centrum semi-ovale, corpus callosum, right } \\
\text { centrum semi-ovale * mid-brain * pons* }\end{array}$ \\
\hline $\begin{array}{l}\text { Henson and } \\
\text { Russell (1942) }\end{array}$ & $\begin{array}{l}\text { Central third of white matter of both cerebral } \\
\text { hemispheres, corpus callosum, }{ }^{*} \text { pons* }\end{array}$ \\
\hline $\begin{array}{l}\text { Shallard and } \\
\text { Latham (1945) } \\
\text { MacArdle et al. }\end{array}$ & $\begin{array}{l}\text { Central white matter of left cerebral hemisphere. } \\
\text { cerebellum* }\end{array}$ \\
\hline $\begin{array}{l}(1949): \\
\text { Case 1 }\end{array}$ & $\begin{array}{l}\text { Central white matter of both hemispheres, } \\
\text { cerebral peduncles, pons, cerebellum* }\end{array}$ \\
\hline,$\quad 2$ & $\begin{array}{l}\text { Central white matter of both hemispheres, left } \\
\text { more affected than right }\end{array}$ \\
\hline Greenfield (1950) & $\begin{array}{l}\text { Central white matter of both hemispheres. } \\
\text { corpus callosum, pons* }\end{array}$ \\
\hline $\begin{array}{l}\text { Present author: } \\
\text { Case } 1\end{array}$ & $\begin{array}{l}\text { White matter of both hemispheres, mid-brain, } \\
\text { pons }\end{array}$ \\
\hline, 2 & $\begin{array}{l}\text { Left temporal white matter, central white matter } \\
\text { of both hemispheres }\end{array}$ \\
\hline, 3 & $\begin{array}{l}\text { Central white matter of both hemispheres. mid- } \\
\text { brain, cerebral peduncles, cerebellum, pons }\end{array}$ \\
\hline
\end{tabular}

* These regions showed microscopical lesions only.

spared. The corpus callosum has shown nakedeye lesions in half the cases. The level to which the lesions descend has varied greatly in the 10 cases. They have been noted in the cerebral peduncles in three cases and in the pons in four, but Case 3 of the present series is the first in which they are recorded in the white matter of the cerebellar hemispheres (Fig. 2), though other cases have shown microscopic lesions there.

\section{Histopathology}

The distribution of the microscopic lesions (Table III) is more widespread than of the nakedeye lesions, but the former, like the latter, are virtually limited to the white matter. They extend over a wider area of the hemispheres and to a lower level in the brain stem, the cerebellum being quite frequently involved (three cases). It is convenient for descriptive purposes to consider the different types of microscopic lesion separately. but it must be emphasized that a combination of $\stackrel{5}{+}$ lesions may occur at a single site: for example. 을 haemorrhage, demyelination, and neurofibril dis- $\frac{\bar{O}}{\bar{D}}$ integration.

Haemorrhage.-The haemorrhages are the most conspicuous lesion in ordinary preparations. क Their structure is best studied in less severely $\vec{\circ}$ affected areas where they are small and discrete. $\overrightarrow{\vec{\omega}}$ Two types are described : ball haemorrhages and $\stackrel{\omega}{\omega}$ ring haemorrhages (Fig. 3). The ball haemorrhage $\overline{0}$ is a minute sphere of extravasated blood, and $-v$ serial sectioning will usually reveal a disrupted $-\overrightarrow{-}$ capillary in its centre (Fig. 4), but the ring haemor- $\overrightarrow{0}$ rhage has a non-haemorrhagic centre in which it $\frac{}{5}$ is often possible to find a capillary plugged with $\vec{T}$ fibrin. Owing to the rapidly fatal course of the $\mathbb{D}$ disease the extravasated red corpuscles appear intact in sections and have not lost their haemoglobin.

Two types of exudate may also be distinguished. cellular exudate and serous exudate. A moderate collection of leucocytes may be seen in the perivascular space around many of the small venules in an affected part (Fig. 5). In transverse section the cells often form an asymmetrical bulge, breaking out from the vessel sheath and spreading into $\mathbb{Q}$ the adjacent brain tissue. A high proportion of $\overrightarrow{\overrightarrow{0}}$ the cells are neutrophil polymorphonuclear leuco- 3 cytes. There is a varying admixture of lymphocytes and histiocytes, but plasma cells and eosinophils have not been noted.

The appearance referred to as "serous exudate. 응 is a rather striking finding seen in all three cases 3 . of the present series and well illustrated by Henson and Russell (1942). It consists of homogeneous. indifferently staining material distending the perivascular sheath and in places bursting out into the adjacent white matter. Sometimes there is considerable contamination with red blood corpuscles.

Lesions in Blood Vessels. - The lesions in the blood vessels constitute what are perhaps the most 0 characteristic microscopic features of the disease. $\omega$ The small venules of the white matter are the vessels most affected but there are lesions also in 0 the capillaries and sometimes in small arterioles. The most characteristic lesion is shown in Fig. $6 . \stackrel{+}{+}$ It consists of impregnation or replacement of the $\frac{7}{0}$ tissues forming the vessel wall with material giving $\frac{\vec{D}}{\mathbb{0}}$ the staining reactions of fibrin, while similar $\frac{\rho}{\Phi}$ material is present in varying amounts in the $\stackrel{\unrhd}{\varrho}$ perivascular space. A modification of this lesion is depicted in Fig. 7 in which the fibrin 8 impregnation extends beyond the vessel wall and 
perivascular space far into the surrounding white matter. Sometimes the fibrin-impregnated tissue forms a halo outside an intact vessel wall and sheath, while another appearance (Fig. 8) is of a plastering of fibrin around the inside of the vessel wall often extending through the thin wall to the perivascular sheath. Endothelium may grow over the deposit to line the new narrowed lumen, and the whole appearance is then reminiscent of the description given by Duguid and Anderson (1952) of hyaline sclerosis in the splenic arterioles.

Capillary disruption and obstruction in association with the haemorrhages have already been mentioned. Groups of fibrin-plugged capillaries may also be found without any apparent relationship to haemorrhages (Fig. 9).

The application of myelin stains to this material reveals the presence of widespread foci of demyelination (Fig. 10). Closer inspection shows two types of demyelinated area-irregular patches in and around the areas of haemorrhage (Fig. 11) and narrow zones around small blood vessels (Fig. 12). Cells are scanty in the demyelinated areas. Appropriate staining methods show disruption of the neurofibrils in relation to many of the foci of demyelination. Microglial proliferation occurs in the affected areas and in the cases of longer standing fat phagocytes collect around the degenerate foci.

Cellular degeneration affecting pyramidal and Purkinje cells, astrocytes, oligodendroglial cells, ependymal cells, and cells of the choroid plexus was noted by Henson and Russell (1942), but has not usually been conspicuous.

\section{Discussion}

The addition of these three further cases to the small group of cases already published strengthens Hurst's contention that acute haemorrhagic leucoencephalitis is a specific disease entity distinct from other forms of encephalitis. The specific pathological features which justify the classification of a case into this type of encephalitis are multiple capillary haemorrhages, focal and perivascular demyelination, and the characteristic fibrin impregnation of the vessel walls, with a predominantly polymorphonuclear exudate all virtually limited in their incidence to the white matter.

Search of the literature shows few cases other than the seven already considered which fulfil these conditions. Adams, Cammermeyer, and Denny-Brown (1949), however, described under the name of "acute necrotising haemorrhagic encephalopathy" four cases which, though differing from the accepted cases in detail, did show these main points. Two of the cases occurred in the United States of America and two in Norway. There were three male patients (aged 33, 34, and 46 years) and one female patient (aged 56 years). All showed a prodromal period of upper respiratory infection and all died within 30 to 60 hours of the onset of neurological features. The main differences from the 10 cases discussed above are in the cerebrospinal fluid findings and in the distribution of lesions. The two cases in which cerebrospinal fluid cell counts are recorded showed counts reaching 5,000 and 1,600 per c.mm. with $100 \%$ and $85 \%$ polymorphs. Some rather equivocal findings of pyogenic cocci in the tissues of the former leave doubts as to its true nature. In addition in two of the cases the white matter of the cerebral hemispheres was spared and lesions occurred only in and below the mid-brain.

As regards the differential diagnosis, acute haemorrhagic leuco-encephalitis has to be distinguished from other causes of multiple petechial haemorrhages and other causes of multiple foci of demyelination. Once microscopic sections are available the combination of haemorrhages, demyelination, and fibrin impregnation in and around the vessel walls leaves little doubt of the nature of the disease. The closest mimicry of the naked-eye lesions is sometimes seen in cerebral fat embolism in which haemorrhages may be limited to the white matter. Other forms of brain purpura usually involve grey and white matter alike.

The aetiology of the disease and the pathogenesis of the lesions form an interesting speculation. The main aetiological possibilities to be considered are (1) invasion of the brain tissue by bacteria or virus, (2) direct action of circulating toxins on the brain tissue, and (3) acquired sensitivity of the brain tissue to a circulating antigen. Bacteria have not been demonstrated in any of these cases and search for a virus has not been reported. In Case 3, however, of the present series some cerebral tissue was obtained immediately after death and two injections of this material were given into the thalamic areas of a rhesus monkey. The monkey showed no abnormal signs apart from slight pyrexia for two days. It was killed 31 days after the first injection but the brain and cord showed no evidence of disease. Passage was not carried out. In addition the structural lesions (particularly the vascular disruption and the polymorphonuclear exudate) and the distribution of the lesions are unlike the findings in any known virus disease. The possibility of direct toxic action is supported 
by Hurst's observation (1940) that chronic cyanide poisoning in monkeys could lead to focal demyelination, but in none of the cases of acute haemorrhagic leuco-encephalitis has there been evidence of any direct toxic action of this kind. The third possibility-acquired sensitivity to a circulating antigen-has certain points in its favour. The frequent onset of the brain lesions some days after a respiratory infection is in keeping with the time interval observed with other hypersensitivity states. In particular the lesions are similar to those seen in arsphenamine encephalitis. Russell (1937) described three cases of this condition and drew attention to the evidence suggesting that it was a sensitization phenomenon. More recently Cavanagh (1953) has described somewhat similar lesions in a patient who died with evidence of hypersensitivity following administration of streptomycin and para-amino-salicylic acid. Furthermore the vascular lesion resembles closely that occurring in polyarteritis nodosa and producible experimentally in animals by the repeated injection of foreign protein (Klinge, 1929), while the demyelination can be imitated experimentally in animals by multiple injections of emulsions of brain tissue, with or without certain adjuvants (Rivers, Sprunt, and Berry, 1933 : Rivers and Schwentker, 1935 ; Kabat, Wolf, and Bezer, 1947 ; Lumsden, 1949). The dangers inherent in assuming that similar histological lesions are of similar pathogenesis are well known: nevertheless this similarity of the lesions in the human disease to experimental hypersensitivity lesions and to lesions occurring in drug sensitization is the only positive guide to aetiology in this instance. Clearly, more information is needed on many aspects of the problem, but at present such evidence as there is suggests that the lesions result from hypersensitivity of the brain tissue to a circulating antigen acquired during some upper respiratory infection.

\section{Summary}

Three new cases of acute haemorrhagic leucoencephalitis are described, bringing the total of recorded cases up to 10 . The disease occurs predominantly in young adult males.

The encephalitic stage, which is rapidly fatal, is often preceded by a prodromal period of upper respiratory infection.

Polymorphonuclear leucocytosis in the blood and cerebrospinal fluid is the most striking feature of the clinical pathology. The brain lesions are limited to the white matter and are often maximal in the centrum ovale of the hemispheres. They take the form of capillary haemorrhages, polymorphonuclear and serous exudate, fibrin impregnation of vessel walls, capillary plugging, focal demyelination, and microglial proliferation.

The nature of the lesion is uncertain. Search for a causative virus in material from one case was negative. There is some evidence that the lesions may be associated with acquired sensitivity of the brain tissue to a circulating antigen.

I wish to thank Mr. Wylie McKissock, neurosurgeon to St. George's Hospital, for permission to make use of his case records, and Dr. F. O. MacCallum of the Central Public Health Laboratory for carrying out the animal inoculations with materiai from Case 3.

\section{A P P E N D I X}

\section{Summaries of Case Histories and Post-mortem Findings}

Case 1.- A man. aged 28 years, a radio-operator (aircraft). 12 days before admission to hospital developed a feverish cold which lasted four days. He returned to work but six days later became suddenly severely ill with vomiting. headache, and fever. On admission two days later he was semi-conscious, aphasic, and incontinent. Neurological examination showed a small haemorrhage in the right fundus, equal but sluggishly reacting pupils, and right upper motor neuron facial weakness. The tendon reflexes were increased on the right side and the plantar response was extensor on the right. flexor on the left. A radiograph of the skull showed a slight pineal shift to the right. A left temporal-lobe abscess was suspected but exploration proved negative. Ventriculography showed depression of the body and anterior horn of the left lateral ventricle. Cerebrospinal fluid obtained from the right lateral ventricle was under increased pressure and gave a white cell count of 220 per c.mm. (polymorphs $84 \%$ ) and protein level of $80 \mathrm{mg}$. per $100 \mathrm{ml}$. He gradually became more deeply comatose and died four days from the onset of neurological signs.

At post-mortem examination there was evidence of acute bronchitis but otherwise the findings were limited to the brain and are summarized in Table III. Microscopic examination showed widespread haemorrhagic, exudative. and demyelinating lesions of the types described in the text above. Fibrin infiltration in and around the vessel walls was a conspicuous feature.

Case 2.-A boy, aged 2 years 10 months, was healthy until July 19, 1952, when he developed cough and hoarseness. Two days later he became restless and flushed and vomited repeatedly. That evening he developed left-sided convulsions and was admitted to hospital. The temperature was $104.6^{\circ} \mathrm{F}$. and he had a left hemiplegia and injected tonsils. A white blood count gave 30,000 per c.mm. (polymorphs $81^{\circ} \ldots$ ). The ears were normal. He was given penicillin and his 
temperature fell to normal, but coma and hemiplegia persisted and he was transferred to the neurosurgical centre on July 24 as a possible case of brain abscess. Neurological examination there showed response to painful stimuli only. There was moderate neck rigidity but Kernig's sign was negative. The eyes deviated to the left and upwards, the left pupil larger than the right, the right pupil only reacting to light; the fundi were normal. Other cranial nerve functions were normal. There was paralysis of the left arm and leg with increased tone; abdominal reflexes were present but reduced on the left; the right plantar response was flexor, the left extensor. The cerebrospinal fluid at first (July 21) showed no abnormality and was not re-examined. Ventriculography (July 24) showed some displacement of the ventricles to the left but needling the right hemisphere did not reveal an abscess. The depth of coma increased and he died on July 27.

Post-mortem examination revealed extensive pulmonary oedema with patchy bronchopneumonic consolidation. The brain showed bulging of the right temporal region and on sectioning there was ill-defined, pinkish-grey discoloration of the white matter in this area. Close inspection showed many minute haemorrhagic points in the white matter of both hemispheres. Microscopic examination of the discoloured area showed haemorrhages varying from minute groups of red cells up to areas about $3 \mathrm{~mm}$. in diameter. Many of the haemorrhages had a perivascular distribution, and many of the venules and arterioles showed fibrin impregnation of their walls. Cellular exudate was scanty, but here and there the vessels were surrounded by cuffs of polymorphs and mononuclear cells. Extensive demyelination was present in the discoloured area and many smaller foci of demyelination occurred in adjacent areas of white matter and in the right centrum semi-ovale. The mid-brain, brain-stem, and cerebellum were not involved.

Case 3.-A man, aged 31 years, was employed as a cost accountant. On December 24, 1952, he developed a severe cough and vomited twice. The cough continued and on December 27 he had severe frontal headache with further vomiting. Two days later he drowsy and later unable to recognize his family. Following admission to a local hospital where lumbar puncture was performed (cerebrospinal fluid reported as "cloudy, protein $270 \mathrm{mg}$. per $100 \mathrm{ml}$.") he was transferred to the neurosurgical centre as a case of brain abscess on December 31 . He was then deeply comatose, and examination of the nervous system gave the following positive findings: extensor spasms of upper limbs on painful stimulation; considerable neck rigidity; pupils contracted and unreactive ; limbs extended and spastic but reflexes present and equal; abdominal reflexes absent; right plantar response flexor, left extensor. There was no evidence of otitis, and other systems proved normal. Ventriculography showed a normal ventricular system and the ventricular cerebrospinal fluid contained 150 cells per c.mm. (polymorphs $70 \%$ ) and $140 \mathrm{mg}$. protein per $100 \mathrm{ml}$. His temperature fluctuated from $99^{\circ} \mathrm{F}$. to $101.6^{\circ} \mathrm{F}$. In the early part of his illness he was treated with penicillin and later with streptomycin, but he never regained consciousness and he died on January 3, 1953 , at 11 a.m., five days after the onset of signs of involvement of the nervous system.

At post-mortem examination there was extensive bronchitis and bronchiolitis with patchy bronchopneumonic consolidation of the lower lobes of the lungs. Other positive findings were limited to the brain and are summarized in Table III. Microscopic examination of the brain showed all the types of lesion described above.

\section{REFERENCES}

Adams, R. D., Cammermeyer, J., and Denny-Brown, D. (1949). J. Neuropath., 8, 1.

Cavanagh, J. B. (1953). Journal of Clinical Pathology, 6, 128.

Duguid, J. B., and Anderson, G. S. (1952). J. Path. Bact., 64, 519. Greenfield, J.' G. (1950). Brain, 73, 141.

Henson, R. A., and Russell, D. S. (1942). J. Path. Bact., 54, 227.

Hurst, E. W. (1940). Aust. J. exp. Biol. med. Sci., 18, 201.

(1941). Med. J. Aust., 2, 1.

Kabat, E. A., Wolf, A., and Bezer, A. E. (1947). J. exp. Med., 85, 117.

Klinge, F. (1929). Beitr. path. Anat., 83, 185.

Lumsden, C. E. (1949). Brain, 72, 198.

MacArdle, J., Bogaert, L. van, and Lhermitte, F. (1949). Rev. neurol., Paris, 81, 709 .

Rivers, T. M., and Schwentker, F. F. (1935). J. exp. Med., 61, 689.

Sprunt, D. H., and Berry, G. (1933). Ibid., 58, 39.

Russell. D. S. (1937). J. Path. Bact., 45, 357. atham, O. (1945). Med. J. Aust., 1, 145. 